\begin{tabular}{|l|l|l|}
\hline \multicolumn{2}{|c|}{ PublisherInfo } \\
\hline \hline PublisherName & $:$ & BioMed Central \\
\hline \hline PublisherLocation & $:$ & London \\
\hline \hline PublisherImprintName & $:$ & BioMed Central \\
\hline \hline
\end{tabular}

\title{
Better chips through chemistry
}

\begin{tabular}{|l|l|l||}
\hline \multicolumn{2}{|c|}{ ArticleInfo } \\
\hline \hline ArticleID & $:$ & 3764 \\
\hline \hline ArticleDOI & $:$ & $10.1186 /$ gb-spotlight-20000912-03 \\
\hline \hline ArticleCitationID & $:$ & spotlight-20000912-03 \\
\hline \hline ArticleSequenceNumber & $:$ & 201 \\
\hline \hline ArticleCategory & $:$ & Research news \\
\hline \hline ArticleFirstPage & $:$ & 1 \\
\hline \hline ArticleLastPage & $:$ & 2 \\
\hline \hline & & RegistrationDate : 2000-09-12 \\
ArticleHistory & $:$ & OnlineDate \\
\hline \hline ArticleCopyright & $:$ & BioMed Central Ltd2000-09-12 \\
\hline \hline ArticleGrants & $:$ & \\
\hline \hline ArticleContext & $:$ & 130591111 \\
\hline \hline
\end{tabular}


William Wells

Email:wells@biotext.com

Two papers in the September 8 Science are a testament to the speed at which biological chip formats and standards are evolving. Taton et al. expand on their established method for detecting DNA hybridization using gold nanoparticles attached to a probe (Science 2000, 289:1757-1760). The previous system took advantage of a color change induced upon nanoparticle aggregation, but a new method of nanoparticle-promoted reduction of a silver(I) substrate allows for signal amplification and detection using a conventional flatbed scanner. Compared to a standard fluorescence-based system, the nanoparticle probes show over threefold greater selectivity (thanks to a sharper melting profile) and 100-fold greater sensitivity, making this system particularly suited to analysis of single-nucleotide polymorphisms. Protein arrays, meanwhile, are still in the proof-of-concept stage, and that is what MacBeath and Schreiber provide in the same issue of Science (Science 2000, 289:1760-1763). They use a contact-printing robot, microscope slides, and two attachment chemistries. For large proteins the slides are covered with an aldehyde reagent that reacts with the proteins' free amines; the slide is then blocked with bovine serum albumin (BSA). For smaller proteins and peptides that might be obscured by BSA added at the end, a modified BSA is added to the slide first. It is then deprotected and the spotted proteins bind to it. MacBeath and Schreiber test these systems in three ways. They detect specific binding of proteins to proteins, and of small molecules to proteins, and detect phosphorylation of target proteins. The latter activity is read out by direct photographic development of the slide.At the current densities, 10,000 protein samples can be printed (and successfully detected) in half the area of a standard microscope slide. Now all that is needed is a Herculean effort to express large numbers of proteins in a state compatible with the printing process.

\section{References}

1. Science magazine, [http://www.sciencemag.org/]

2. Selective colorimetric detection of polynucleotides based on the distance-dependent optical properties of gold nanoparticles.

3. The MGuide. Version 2.0, [http://cmgm.stanford.edu/pbrown/mguide/index.html]

4. A highly efficient and robust cell-free protein synthesis system prepared from wheat embryos: plants apparently contain a suicide system directed at ribosomes.

This PDF file was created after publication. 